\title{
The Influence of Organizational Culture, Personality, and Trust toward Organizational Commitment of Outlet Leader in Bank Negara Indonesia, Regional Office, Senayan Jakarta. \\ Dedi Sutan Ardani ${ }^{1}$, Moch. Asmawi ${ }^{2}$, Billy Tunas ${ }^{3}$ \\ ${ }^{1}$ Doctoral Program, Human Resource Management, Jakarta State University And Employee PT. Bank Negara Indonesia \\ ${ }^{2}$ Lecturer, Jakarta State University, Indonesia \\ ${ }^{3}$ Lecturer, Jakarta State University, Indonesia
}

\begin{abstract}
The purpose of this research is to determine the influence of organizational culture, personality, and trust toward organizational commitment of outlet leader in Bank Negara Indonesia, Regional Office, Senayan Jakarta. The study was conducted on organizational commitment of 98 outlet leaders selected from the target population of outlet leaders using a quantitative approach with path analysis method. Hypothesis testing shows: (1) organizational culture has a direct positive effect on organizational commitment; (2) personality has a direct positive effect on organizational commitment; ( 3 trust has a direct positive effect on organizational commitment; (4) organizational culture has a direct positive effect on trust: (5) personality has a direct positive effect on trust (6) organizational culture has a direct positive effect on the personality: To improve the commitment of the organization of outlet leaders in Bank Negara Indonesia, the Regional Office of Senayan Jakarta. It needs to be enhanced organizational culture, personality and trust
\end{abstract}

Keywords: Organzational Culture, Personality, Trust, Organizational Commitment.

\section{Introduction}

As the first bank owned by the Goverment of Indonesia, PT Bank Negara Indonesia (Persero) Tbk established in 1946 started its history by performing its function as a central bank as stipulated in Government Regulation in Lieu of Law no. 2/1946. When viewed from the performance of 130 Outlet BNI in the area of Jakarta Regional Office Senayan, it is seen that the average performance of outlet is still far from expected, then this fact informs that the competence of Outlet Leaders owned BNI Jakarta Senayan Regional Office has not shown maximum performance or not have Strong organizational commitment to BNI's performance.

Based on the observations made by researchers found some things that indicate the lack of organizational commitment Outlet BNI Outlet Jakarta Regional Office Senayan. First, it relates to the inability of Outlet Leaders to motivate their team members, so that team members are enthusiasticless in performing their duties and there is unbelieveable in the Outlet Leader's capability. Second, Outlet Leaders do not have a business strategy or business plan in executing their business, so that activities are not appropriate or even away from the vision and mission of BNI. Third, Outlet Leaders are still working according to their KPI / Job Description or are still working on the comfort zone, working just to abort their KPI without having the desire or initiative to make innovations for business development and Improve business process. Fourth, there are Outlet Leaders who do not want to improve their competence, such as continuing education to higher level, motivational training and seminars, this is necessary considering the increased responsibility and job demands of Outlet Leader. The organization's commitment to outlet leaders is very important in the banking world and the progress of a company. Therefore interested in conducting research related to organizational commitment of PT leaders. BNI Senayan Regional Office. 


\section{Objectives}

The purpose of this study is to analyze the direct influence of organizational culture on organizational commitment, to analyze the direct influence of personality on organizational commitment, to analyze the direct influence of trust on organizational commitment, to analyze the direct influence of organizational culture on trust, to analyze the direct influence of personality on trust, to analyze the direct influence of organizational culture on personality.

\section{Literature review}

\section{Organizational Commitment}

According to Timothy T. Baldwin (2013) defines the organizational commitment as follows, "organizational commitment is an attitude representing the extent to which an employee identifies with his organization and desires to remain a member of the organization". Organizational commitment is an attitude that reflects the extent to which an employee identifies with the organization and the desire to remain an organization member. Organizational commitment of employees can be seen from the attitude of loyalty to the workplace.

Japneet Kaur (2017) describes the organizational commitment in his research as follows: "Literature suggests that development of organizational commitment is a consequence of an individual experiences at work, organizational influences and congruence of value with those prevailing in the organization". The development of organizational commitment is a consequence of individual experience at work, organizational influence, and conformity with the organization. Organizational commitment is the attitude or form of a person's behavior towards the organization in the form of loyalty and achievement of vision, mission, values and goals of the organization.

John W. Newstroom (2015) defines the organizational commitment as follows, "organizational commitment is the degree to which an employee identifies with the organization and wants to participate actively in it". Organizational commitment is the extent to which an employee identifies with the organization and wants to continue actively participating in it. Organizational commitment is as a situation where an employee sides with a particular organization and the purpose of its purpose and its desire to maintain membership in the organization.

From the opinion of experts above so that can be synthesized organizational commitment is a psychological bond of an employee to his organization to want to remain as a member of the organization with an indicator to be loyal to the organization, a sense of ownership of the organization, participate and responsible.

\section{Organizational Culture}

According to Warrick (2017) says many experts define organizational culture as follows: "Many definitions are available to describe culture. Formally, culture can be defined as the predominant beliefs, values, attitudes, behaviors, and practices that are characteristic of a group of people". Many definitions are available to describe the culture. Formally, culture can be defined as the dominant beliefs, values, attitudes, behaviors, and dominant practices that characterize a group of people.

According to Jenifer M. George, and Gareth R. Jones (2013) define the organizational culture as follows, "organizational culture is the set of shared values, beliefs and norms that influences the way employees think, feel and behave toward people outside the organization". Organizational culture is a shared set of values, beliefs and norms that affect the way employees think, feel and behave towards people outside the organization. Organizational culture needs to be developed in accordance with the development of the organization's environmental needs. The development of organization on the creation of achievement culture, the type of culture that encourages and appreciates the performance of employees.

John R. Schermerhorn (2013) defines the organizational culture as follows, "organizational culture is the system of shared beliefs and values that shapes and guides the behavior of its members". Organizational culture is a system of beliefs and shared values that form and serve as a guide to the behavior of its members. Organizational culture grows through the evolutionary process of ideas created by organizational education and is then instilled into its followers. organizational culture grows and develops is done by planting through the process of learning and experience.

From the above description can be synthesized that Organizational culture is the value and norms that are mutually agreed upon and firmly held by members in an organization to serve as a guide to do their work to 
support the achievement of organizational goals with indicators: norms, rules applicable, symbols, values, follow adherence and behavioral guidance .

\section{Personality}

We all have different personalities. When we speak of a person's personality, we do not mean that the person has charisma or is constantly smiling. As an organizational behavioralist, we are explaining a dynamic concept of the growth and development of one's personality. Personality is the whole way an individual reacts and interacts with other individuals. Personality is most often described in terms of measurable properties indicated by a person. According to Ricky W. Grifin, and Gregory Moorhead (2014) define the personality as follows, "personality is the relatively stable set of psychological attributes that distinguish one person from another". Personality is a relatively stable set of psychological attributes that distinguishes one from another. Defines the personality we use most often formulated by Gordon Allport around 70 Years ago.

Robert Kreitner, and Angelo Kiniciki (2011) define the personality as follows, "personality is defined as the combination of the stable physical and mental characteristics that give the individual his or her identity." Personality as a combination of stable physical and mental characteristics that give its individual identity. These characteristics or traits include how one sees, thinks, acts, and feels the product of genetic interaction and environmental influences.

From the description above can be synthesized personality is a dynamic and integrated person manifested in the way of thinking, feeling and acting uniquely and stable that characterizes a person's response to the situation around him with an indicator of sincerity, friendliness, caution, emotional stability and openness experience.

\section{Trust}

Trust is defined as a measure of how many employees want information, to work with each other and not to take advantage of others. Trust is the most sensitive issue in international organizations and businesses. According to Jason A. Colquitt, et.al (2015) defines, "Trust is defined as the willingness to be authorized by an authority on the positive expectations of the authority's actions and intentions." Trust as a willingness to accept criticism of authority based on positive expectations about orotiritas and intentions.

According to Jennifer M. George, and Gareth Jones stated, "trust is the willingness of one person or group to have faith or confidence in the goodwill of another person, even though this puts them at risk (because the other might act in a deceitful way". Trust is the willingness of a person or group to have faith or trust in the goodwill of another, even if it puts them at risk (because others may act deceptively).

Suzanne C. de Janasz, Karen O. Dowd, and Beth Z. Schneider (2012) define trust as follows, "trust is a multifaceted concept that captures one's faith or belief in the integrity and reliability of another person or thing". Trust is a multifaceted concept that captures one's faith or trust in the integrity and reliability of the person or another. Trust is defined as a belief in attitudes and behavior between one person and another.

From the description above can be synthesized belief is a person's belief in others in speech and action in relation to indicators of sharing information with others, cooperating with others, not taking advantage of others, completing work on time and keeping promises.

Based on the literature reviewed, the following hypotheses were formulated :

H1. Organizational Culture has a direct positive effect on Organizational Commitment

H2. Personality has a direct positive effect on Organizational Commitment

H3. Trust has a direct positive effect on Organizational Commitment

H4. Organizational Culture has a direct positive effect on Trust

H5. Personality has a direct positive effect on Trust

H6. Organizational Culture has a direct positive effect on Personality

Conceptual Framework 


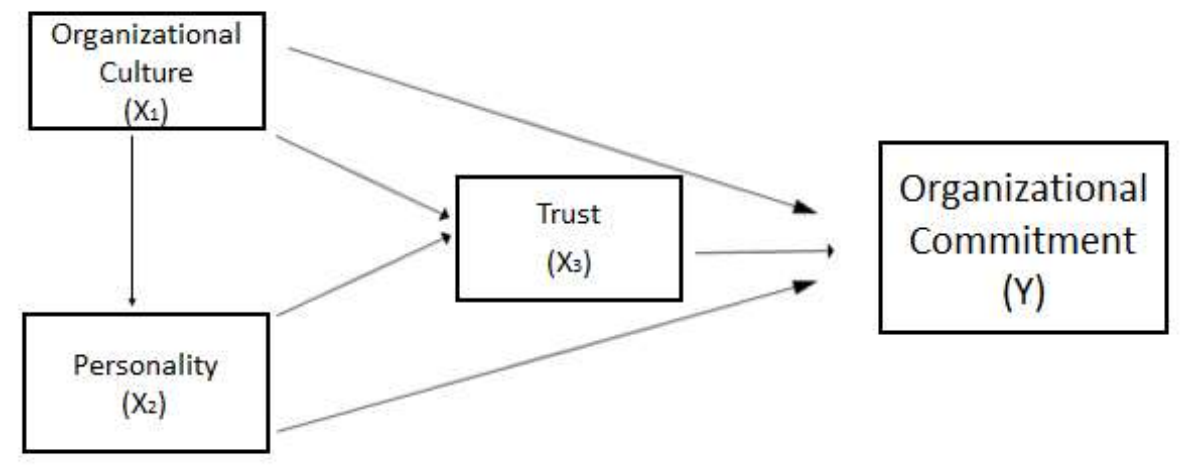

\section{Research Methodology}

The population that is all of outlet leader in Bank Negara Indonesia. The large number of samples used simple random sampling with the assumsion that all population have the same characteristic (homogent). This research in Indonesia. Uses quantitative approach strategy with survey method. It's about 130 of outlet leader in Bank Negara Indonesia. The large number of samples to be taken in this research was there was a total of 98 outlet leader with simple random sampling. The collect of data use the question and analysis with path analysis

\section{Result}

Table 1.

Coefficient Sub- Structure1

Coefficients $^{\mathrm{a}}$

\begin{tabular}{|c|c|c|c|c|c|c|}
\hline \multirow{2}{*}{\multicolumn{2}{|c|}{ Model }} & \multicolumn{2}{|c|}{$\begin{array}{l}\text { Unstandardized } \\
\text { Coefficients }\end{array}$} & $\begin{array}{l}\text { Standardized } \\
\text { Coefficients }\end{array}$ & \multirow[t]{2}{*}{$\mathrm{t}$} & \multirow[t]{2}{*}{ Sig. } \\
\hline & & $\mathrm{B}$ & Std. Error & Beta & & \\
\hline \multirow{4}{*}{1} & (Constant) & 14,720 & 11,894 & & 1,238 & ,219 \\
\hline & $\mathrm{X} 1$ & ,215 & ,083 & ,228 & 2,586 & ,011 \\
\hline & $\mathrm{X} 2$ & ,225 & ,065 & 306 & 3,448 & 001 \\
\hline & $\mathrm{X} 3$ & ,320 & ,098 & ,295 & 3,273 & ,001 \\
\hline
\end{tabular}

a. Dependent Variable: Y

Equation Structure formed on this sub structure first model formed by the line coefficients of variable $x_{1}$ to $y, x_{2}$ to $y$, and the line coefficients of $x_{3}$ varible to $y$ in the form of $: y=p_{y 1} x_{1}+p_{y 2} x_{2}+p_{y 3} x_{3}+p_{y} \varepsilon_{1}$. With large $\left(R_{\mathrm{y} .123}\right)^{2}=0,393$ so $p_{\mathrm{y}} \varepsilon_{1}=0,607$. So as to form structural equation on model sub structure first: $Y=$ $0,228 \mathrm{x}_{1}+0,306 \mathrm{x}_{2}+0,295 \mathrm{x}_{3}+0,607$

Tabel 2.

Coefficient Sub- Structure2

Coefficients $^{\mathrm{a}}$

\begin{tabular}{|cc|c|c|c|c|c|}
\hline \multirow{2}{*}{ Model } & \multicolumn{2}{|c|}{$\begin{array}{c}\text { Unstandardized } \\
\text { Coefficients }\end{array}$} & $\begin{array}{c}\text { Standardized } \\
\text { Coefficients }\end{array}$ & \multirow{2}{*}{$\mathrm{t}$} & \multirow{2}{*}{ Sig. } \\
\cline { 3 - 4 } & & $\mathrm{B}$ & Std. Error & Beta & & \\
\hline \multirow{2}{*}{1} & (Constant) & 65,822 & 10,504 & & 6,266 &, 000 \\
& X1 &, 236 &, 084 &, 270 & 2,802 &, 006 \\
& X2 &, 196 &, 065 &, 288 & 2,985 &, 004 \\
\hline
\end{tabular}

a. Dependent Variable: X3 
Equation structure formed on this sub structure second model formed by the line coefficients of variable $\mathrm{x}_{1}$ to $\mathrm{x}_{3}, \mathrm{x}_{2}$ to $\mathrm{x}_{3}$, or as: $\mathrm{x}_{3}=\mathrm{p}_{31} \mathrm{x}_{1}+\mathrm{p}_{32} \mathrm{x}_{2}+\mathrm{p}_{3} \varepsilon_{2}$. With large $\left(\mathrm{R}_{3.12}\right)^{2}=0,206$ so $\mathrm{p}_{4} \varepsilon_{2}=0,794$. So as to form structural equation on model sub second structure : $X_{4}=0,270 x_{1}+0,2886 x_{2}+0,794$.

Tabel 3.

Coefficient Sub- Structure3

Coefficients $^{\mathbf{a}}$

\begin{tabular}{|c|c|c|c|c|c|}
\hline \multirow[t]{2}{*}{ Model } & \multicolumn{2}{|c|}{$\begin{array}{l}\text { Unstandardized } \\
\text { Coefficients }\end{array}$} & $\begin{array}{l}\text { Standardized } \\
\text { Coefficients }\end{array}$ & $\mathrm{t}$ & Sig. \\
\hline & $\mathrm{B}$ & Std. Error & Beta & & \\
\hline $\begin{array}{ll}1 & \text { (Constant) } \\
\mathrm{X} 1\end{array}$ & $\begin{array}{r}62,758 \\
.409\end{array}$ & $\begin{array}{r}15,065 \\
, 124\end{array}$ & 319 & $\begin{array}{l}4,166 \\
3,297\end{array}$ & $\begin{array}{l}, 000 \\
.001\end{array}$ \\
\hline
\end{tabular}

a. Dependent Variable: X2

Equation structure formed on this sub structure third model formed by the line coefficients of variable $\mathrm{X}_{1}$ to $\mathrm{X}_{2}$ or as: $\mathrm{X}_{2}=\mathrm{p}_{21} \mathrm{X}_{1}+\mathrm{p}_{2} \varepsilon_{3}$. With large $\left(\mathrm{R}_{2.1}\right)^{2}=0,102$ so $\mathrm{p}_{2} \varepsilon_{3}=0,938$. So as to form structural equation on model sub third structure : $X_{2}=0,319 X_{1}+0,898$.

Structure a diagram of a whole of a track any structure is presented in this figure:

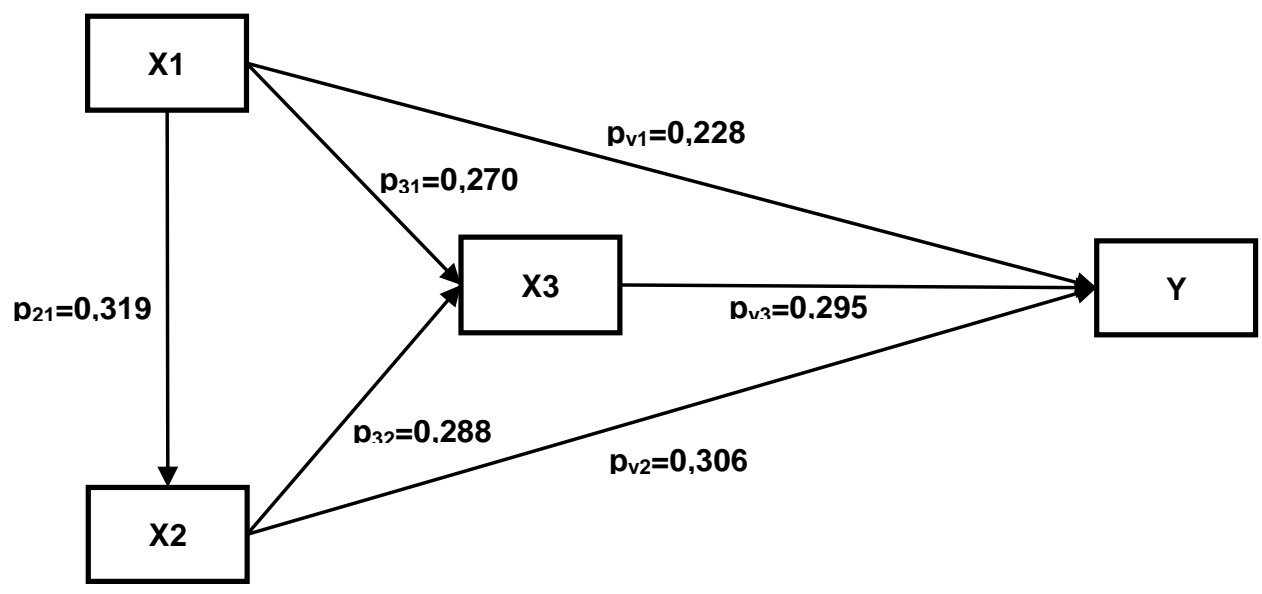

A Diagram Causal Influence $X_{1}, X_{2}$ and $X_{3}$ to $Y$

\section{Discussion}

Based on the analysis and the hypotheses shows that sixth hypothesis advanced by the research was generally proved every lines has a direct positive effect. In detail, the analysis and the testing of hypotheses research is described as follows:

\section{Influence Organizational Culture to Organizational Commitment}

The organizational culture direct positive effect to organizational commitment. Based on finding the result it can be concluded that the organizational commitment affected direct positive effect to organizational culture. Increasing organizational culture will result in improved organizational commitment. The results of these studies were with some expert opinions which are Jason A. Colquitt et.al (2015) mengatakan, "this view assumes that the organization has a strong culture and definite norms and values that is wants employees to adopt, which is not always the case. Some organizations don't have strong culture that they want employees to adapt to, or they might be trying to change their culture and want new employees to come in and shake things up".

\section{Influence Personality to Organizational Commitment}


Personality direct positive effect to the organizational commitment. Based on finding the result that organizational commitment positive direct influenced by personality. The increase of personality wil results in an increase of organizational commitment. The result of this research tune with statement from many expert among others Steven L. McShane and Mary Ann Von Glinow (2010) said, "organizational commitment refers to the employee's emotional attachment to, identification with, and involvement a particular in organization".

\section{Influence Trust to Organizational Commitment}

Trust there is direct positive effect to organizational commitment. Based on finding the result that organizational commitment direct influenced by trust. The increase of trust will results in an increase of organizational commitment. The result of this research tune with statement from jason a.Colquitt, et.al (2015) said trust can be defined on hope positive of an act of authority and intention. When we believe, we become was willing to put your self out there. A further Jason A. Colquitt et al said "trust has a strong positive effect on commitment. Employees who are willing to be vulnerable to authorities tent to have higher levels of affective commitment and higher levels of normative commitment. Trust has no effect on continuance commitment".

\section{Influence Organizational Culture toTrust}

Organizational is direct positive effect to trust. Thus can be concluded that trust influenced direct positive to organizational culture. The increase of organizational culture will results in an increase of trust. According to atikson (2010) organizational culture as reflect assumptioin underlying about how it works performed: what is acceptable and unacceptable and all behavior and the act of driven and despair, definition more detailed is: "the collection of traditions, values, policies, beliefs and attitudes that constitute a pervasive context for everything we do and think in an organization".

\section{Influence Personality to Trust}

Personality direct positive effect to trust. Based on the results of these findings it can be concluded that trust influenced positive direct to personality. Increase in personality will results in an increase of trust. Trust can be defined as the characteristics of the individual who relatively perennial and disposition that form patterns distinguish one person from the other. Suzanne C. de Janasz, Karen O. Dowd, and Beth Z. Schneider (2012) said "personality describe the relatively stable of characteristic, tendencies, and temperaments that have a been formed by heredity and by social, cultural and environmental factors".

\section{Influence Organizational Culture to Personality}

Organizational culture direct positive effect to personality. Based on the results of these findings it can be concluced that personality influenced positive direct to organizational culture, Jason a. colquit (2011) said "organizational culture as the shared social knowledge within an organization regarding the rules, norm and values that shape the attitude and behavior of it employees. The Influence of Organizational Culture, Personality, and Trust toward Organizational Commitment of Outlet Leader in Bank Negara Indonesia, Regional Office, Senayan Jakarta.

\section{Conclusions}

The conclusion of this research shows that there is direct positive influence of organizational culture, personality, trust, and organizational commitment. There is a direct positive influence of organizational culture to organizational commitment, trust is a direct influence to organizational commitment, trust is a direct influence to the organizational commitment, organizational culture is a direct influence to the trust, personality is a direct influence to the trust, organizational culture is a direct influence to personality.

\section{Recommendation}


Organizational culture, personality and trust direct positive effect to the organizational commitment. Organizational commitment can increase, personality, trust, organizational culture it is very important for the company, role in improving of employee performance and organizational performance. And then for further researchers to continue this research with different independent variables such as employee performance, employee commitment, because these variables can effect to the prganizational commitment.

\section{References}

1. Baldwin, Timothy T., William H. Bommer, Robert S. Rubbin, Managing Organizational Behavior what Great Managers Know \& Do Second Edition. New York: Mc Graw Hill, 2013.

2. Bateman. Thomas S., Scoot A. Snell, Managemenet Leading \& Collaborating in a Competitive World 11 edition. New York:McGraw-Hill, 2015.

3. Cassiy. Carlene M., Robert Kreitner, Principles of Management 12 Edition. Asia:South-Western Cengange Learning, 2011.

4. Colquitt, Jason A. Jeffry A. LePine, Michael J Wesson, Organizational Behavior: Improving Performance and Commitment in the Worplace 4 edition. New York: McGraw-Hill, Companies, Inc., 2015.

5. De Janasz, Suzanne C., Karen O. Dowd, Beth Z. Schneider, Interpersonal Skill in Organization 14 edition. New Yok: McGraw Hill, 2012.

6. George, Jennifer M Gareth Jones, Contemprary Management Global Edtition. New York: Mc Graw Hill, 2014.

7. George, Jennifer M. Gareth R. Jones, Understanding and Managing Oganization Behavior, Sixth Edition. New Jersey: Pearson Prantice Hall, 2012.

8. Gibson, James L., John M. Ivancevich,James H. Donnelly, Jr, Robert Konopaske, Organizations Behavior, Structure, Processes 14 edition.New York:McGrwa-Hill,2012.

9. Gomez-Mejia. Luix R., David B. Balkin, Management People Perfromance Change. New Jersey: Pearson, 2012.

10. Greenberg, Jerald, Behavior in organizations 10 edition. England: Pearson, 2011.

11. Greenberg, Jerald. Robert A. Baron. Behavior in Organization 9 edition. New Jersey: Pearsin Prentice Hall,2008.

12. Griffin, Ricky W., Gregory Moorhead, Organizational Behavior: Managing People and Organizations, Eleventh Edition. South-Western, Cengange Learning, 2014.

13. Griffin, Ricky W., Management Principles and Practices 11 Edition. New York:McGraw-Hill, 2013.

14. Heneman III, Herbert G. Timothy A. Judge, John Kammeyer Mueller, Staffing Organizations 8 edition. New York: McGraw Hill, 2015.

15. Hitt, Michael A., J. Stewart Black. Lyman W. Porter, Management 3 Edition. New Jersey: Pearson, 2012.

16. Ivancevich. John M., Robert Konopakse, Michael T. Matteson, Organizational behavior \& Management 10 Edition. New YorK: McGraw Hill, 2014.

17. Jones, Gareth R., Organizational Theory, Design and Change 7 Edition. England:Pearson, 2013.

18. Kinicki, Angelo, Brian Williams, Management a Practical Introduction. New York: McGraw Hill, 2011.

19. Kinicki, Angelo, Robert Kreitner, Organizational Behavior 9 Edition. New York, McGraw Hill, 2011.

20. Kreitner, Robert, Management 11 Edition. Canada:Hought Mifflin Harcourt publishing company,2009.

21. Luthans, Fred, Organization Behavior An Evidence-Based Approach 12 Edition. New York:McGrawHill,2011.

22. McShane, Steven L. Mary Ann Von Glinov, Organizational Emerging Knowledge and Pactice for The Real World. New York: McGraw Hill, 2010.

23. McShane, Steven. Mara Olekalns, Tony Travaglione, organizational behavior emerging knowledge. Global insight 4 edition. Asia: McGraw Hill, 2013.

24. Mullins, Laurie J., Management And Organisational Behavior, Seventh Edition. London: Prentice Hall, 2005.

25. Newstroom, John W., Organizational behavior human behavior at work 14 edition (New York: McGraw-Hill, 2015. 
26. Newstroom. John W., Keith Davis, Organizational Behavior Human Behavior at Work 10 Edition. New York:McGraw-Hill, 1997.

27. Quick, James Campbell, Debra L. Nelson, Principles of organizational behavior realities and challenges 8 edition. USA: South Western Cengange Learning, 2013.

28. Robbins, Stephen P, Mary Coulter, Managemnet 12 edition. New York: McGraw Hill, 2014.

29. Robbins, Stephen P., Timothy A. Judge, Organizational Behavior 16 edition. England: Pearson, 2015.

30. Schemerhorn, John R., JR, Richard N. Osborn, Mary Uhl-Bien, James G. Hunt, Organizational Behavior 12 edition. Asia: Wiley, 2012.

31. Schermerhon, John R., Introduction to Management 12 edition.Asia; Wiley, 2013..

32. Schermerhorn, John R. Jr,Daniel G. Bachrach, Introduction to Management 13 edition. USA:Wiley, 2015.

33. Schermerhorn. John R. Jr, Paul Davidson, David Poole, Peter Woods, Alan Simon, Ellen McBaron, Management 5 edition Australia: Wiley, 2014.

34. Slocum, John W., Don Hellriegel, Principles of Organizational Behavior 13 edition. China: SouthWestern, 2011.

35. Vecchio, Robert P.. Organizational Behavior: Core Concept,6th Edition. Ohio: Thompson Corporation, 2006.

36. Walker, Anthony, Organizational Behavior in Contsruction. UK:Wiley BlackWell, 2011. 